\title{
KAJIAN RELIABILITAS PADA SISTEM SERI-PARALEL DENGAN EMPAT KOMPONEN
}

\author{
Farhah Izzatul Jannah $^{1}$, Sudarno ${ }^{2}$,Alan Prahutama ${ }^{3}$ \\ 1,2,3 Departemen Statistika, Fakultas Sains dan Matematika, Universitas Diponegoro \\ e-mail : farhah.izzatul39@gmail.com
}

\begin{abstract}
Reliability analysis is the analysis of the possibility that the product or service will function properly for a certain period of time under operating conditions without failure. One configuration of components that can be formed is a series-parallel system on a filter capacitor circuit using 4 components consisting of 2 rectifier diodes, 1 capacitor, and 1 load resistor. The data used to obtain the value of system reliability is the time of failure based on the assumption of failure of the independent component. The function of the form on the system can be expressed by $\Phi(\boldsymbol{x})=x_{1} x_{3}+x_{1} x_{4}+x_{2} x_{3}+x_{2} x_{4}-x_{1} x_{3} x_{4}-x_{2} x_{3} x_{4}-x_{1} x_{2} x_{3}-x_{1} x_{2} x_{4}+x_{1} x_{2} x_{3} x_{4}$. The parameter values of each distribution are calculated using the Median Rank Regression Estimation (MRRE) and Maximum Likelihood Estimation (MLE) methods. To test the data following a certain distribution or not, the calculation is manually done with the Anderson-Darling (AD) test so that it is known that the failure time data of rectifier diode 1 follows the weibull distribution with parameters $\hat{\beta}=13,313$ and $\hat{\eta}=42119,960$, failure time data of rectifier diode 2 follows weibull distribution with parameters $\hat{\beta}=20,831$ and $\hat{\eta}=42776,606$, failure time data of capacitors follow normal distribution with parameters $\hat{\mu}=42966,192$ and $\hat{\sigma}=384,337$, and the failure time data of the load resistor following the gamma distribution with parameters $\hat{\alpha}=371,997$ and $\hat{\beta}=115,910$. From the calculation of system reliability, it shows that the higher the intensity of the system fails it will affect the value of reliability to be lower. A serial system from a parallel system functions if there is at least one component $\mathrm{j}$ in one subsystem that functions.
\end{abstract}

Keywords: Reliability, Series-Parallel, MRRE, MLE, AD.

\section{PENDAHULUAN}

Pada mulanya statistika hanya menyangkut urusan-urusan negara, jadi sesuai dengan namanya, tetapi sekarang telah meluas sampai ke bidang pertanian, biologi, bisnis, elektronik, dan lain sebagainya (Spiegel, 1988). Seperti dengan topik penelitian yang dikaji dalam penelitian ini mengenai analisis reliabilitas pada sistem elektronik komponen seriparalel yang diaplikasikan melalui rangkaian sistem filter kapasitor pada power supply guna mengetahui ketahanan hidup komponen dan sistem tersebut.

Menurut Elsayed (1996) sistem merupakan kumpulan dari komponen yang dirangkai berdasarkan desain tertentu untuk mencapai fungsi yang diinginkan dengan kinerja yang dapat diterima dan ukuran keandalan, sedangkan komponen dapat didefiniskan sebagai bagian atau unsur yang digunakan untuk menunjang suatu sistem.Komponen dalam sistem dapat disusun dengan beberapa konfigurasi sistem komponen antara lain 1) sistem komponen seri, 2) sistem komponen paralel, 3) sistem komponen paralel-seri atau seriparalel yang mana beberapa komponen terhubung secara seri dan lainnya terhubung secara paralel, dan 4) sistem komponen kompleks seperti jaringan-jaringan (Elsayed, 1996).

Menurut Elsayed (1996), analisis reliabilitas merupakan analisis kemungkinan bahwa produk atau layanan akan beroperasi dengan benar selama periode waktu tertentu di bawah kondisi operasi tanpa kegagalan. Tujuan analisis ini ialah untuk menunjukkan lamanya waktu hidup suatu produk atau layanan yang diukur dari titik waktu tertentu sampai unit tersebut tidak dapat berfungsi lagi dengan normal. Fungsi pengukuran reliabilitas yang digunakan ada tiga, diantaranya fungsi kepadatan peluang, fungsi ketahanan hidup, dan fungsi kegagalan. 
Telah dilakukan beberapa studi kasus mengenai peranan analisis reliabilitas khususnya pada rangkaian sistem komponen seperti kajian availabilitas oleh Anugraheni (2013), kajian reliabilitas dan availabilitas paralel oleh Pradewi (2014), dan kajian reliabilitas pada data waktu kegagalan konfigurasi rangkaian lampu LED pada PCB lampu yang menghasilkan nilai reliabilitas pada komponen dan sistem rangkaian paralel-seri oleh Nuroqi (2017).

Data yang akan dikaji merupakan data bangkitan dengan variabel waktu kegagalan komponen berdasarkan contoh studi kasus yang diangkat menjadi objek penelitian, meliputi dioda penyearah $1\left(\mathrm{~T}_{\mathrm{D} 1}\right)$ dan dioda penyearah $2\left(\mathrm{~T}_{\mathrm{D} 2}\right)$ yang dibangkitkan dengan distribusi Weibull, kapasitor $\left(\mathrm{T}_{\mathrm{K}}\right)$ yang dibangkitkan dengan distribusi normal, dan resistor beban $\left(T_{R}\right)$ yang dibangkitkan dengan distribusi gamma.

\section{TINJAUANPUSTAKA}

\subsection{Ruang Sampel}

Percobaan adalah proses untuk menghasilkan atau membangkitkan observasi sedangkan himpunan dari semua peristiwa yang dapat terjadi dari suatu akibat percobaan dinamakan Ruang Sampel, dilambangkan dengan S. Dalam Ruang Sampel, apabila hasil dari suatu percobaan terdapat jumlah yang terhingga atau tak terhingga terhitung (countable) dinamakan ruang sampel diskrit dan apabila ruang sampel tak terhitung (uncountable) maka $\mathrm{S}$ merupakan interval riil yang dinamakan ruang sampel kontinu (Bain dan Engelhardt, 1992).

\subsection{Variabel Random}

Menurut Bain dan Engelhardt (1992) variabel randomXadalah suatufungsi dengan daerah asal $\mathrm{S}$ dan daerah hasil bilangan real $\mathrm{R}$ sedemikian sehingga $X(e)=x$ dimana $e \in S$ dan $x \in R$.

\subsection{Distribusi Peluang Kontinu}

Menurut Bain dan Engelhardt (1992), jika $X$ merupakan peubah acak kontinu, maka fungsi peluang untuk peubah acak kontinu dinamakan fungsi densitas peluang $f(x)$. Suatu variabel acak $X$ dikatakan kontinu jika fungsi $f(x)$ memenuhi syarat sebagai berikut:

1. $f(x) \geq 0$

2. $\int_{-\infty}^{\infty} f(x) d x=\lim _{a \rightarrow \infty} \int_{-a}^{a} f(x) d x=1$

3. $P(a \leq X \leq b)=\int_{a}^{b} f(x) d x$

Tabel 1. Fungsi Densitas dan Distribusi Kumulatif

\begin{tabular}{lcc}
\hline Distribusi & $\boldsymbol{f ( x )}$ & $\boldsymbol{F}(\boldsymbol{x})$ \\
Normal & $f(x)=\frac{1}{\sigma \sqrt{2 \pi}} \exp \left(-\frac{1}{2}\left(\frac{x-\mu}{\sigma}\right)^{2}\right)$ & $F(x)=\Phi\left(\frac{x-\mu}{\sigma}\right)$ \\
Gamma & $f(x)=\frac{x^{\alpha-1}}{\Gamma(\alpha) \beta^{\alpha}} e^{\frac{-x}{\beta}}$ & $F(x)=1-e^{\frac{-x}{\beta}} \sum_{k=0}^{n-1} \frac{\left(\frac{x}{\beta}\right)^{k}}{k !}$
\end{tabular}


Weibull $\quad f(x)=\frac{\beta}{\eta}\left(\frac{x-\gamma}{\eta}\right)^{\beta-1} \exp \left[-\left(\frac{x-\gamma}{\eta}\right)^{\beta}\right] F(x)=1-\exp \left(-\left(\frac{x}{\eta}\right)^{\beta}\right)$

\subsection{Metode Estimasi Parameter}

Parameter merupakan karakteristik yang menentukan jenis suatu distribusi terhadap sebuah fungsi. Pada umumnya harga dari suatu parameter populasi tidak diketahui, sehingga perlu diestimasi berdasarkan pengamatan data sampel.

\subsubsection{Maximum Likelihood Estimation (MLE)}

Maximum Likelihood Estimation (MLE) merupakan salah satu metode yang digunakan untuk menaksir parameter dari suatu populasi jika distribusi populasi tersebut telah diketahui. Dalam Bain dan Engelhardt (1992), dimisalkan $X_{1}, X_{2}, \ldots, X_{n}$ adalah sampel random dari populasi dengan densitas $f\left(x \mid \theta_{1}, \theta_{2}, \ldots, \theta_{k}\right)$, fungsi likelihood didefinisikan dengan :

$$
\mathrm{L}\left(\theta_{1}, \theta_{2}, \ldots, \theta_{k} \mid \underset{\sim}{\mathrm{X}}\right)=\prod_{i=1}^{n} f\left(x_{i} \mid \theta_{1}, \theta_{2}, \ldots, \theta_{k}\right) \text {. }
$$

Bila fungsi likelihood ini terdiferensialkan dalam $\theta_{1}, \theta_{2}, \ldots, \theta_{k}$ maka calon estimator maksimum likelihood yang mungkin adalah harga-harga $\left(\hat{\theta}_{1}, \hat{\theta}_{2}, \ldots, \hat{\theta}_{k}\right)$ sehingga:

$$
\frac{\partial L\left(\theta_{1}, \theta_{2}, \ldots, \theta_{k} \mid \underset{\sim}{X}\right)}{\partial \theta}=0
$$

Untuk membuktikan bahwa $\hat{\theta}_{i}$ benar-benar memaksimumkan fungsi likelihood $\mathrm{L}\left(\theta_{1}, \theta_{2}, \ldots, \theta_{k} \mid \mathrm{X}\right)$ harus ditunjukkan bahwa:

$$
\left.\frac{\partial^{2} L\left(\theta_{1}, \theta_{2}, \ldots, \theta_{k} \mid \underset{\sim}{X}\right)}{\partial \theta_{i}^{2}}\right|_{\theta_{i}=\hat{\theta}_{i}}<0
$$

Budhi (2001) telah membuktikan bahwa estimator yang diperoleh pada MLE merupakan estimator yang telah memaksimumkan fungsi log likelihood. Dimisalkan fungsi dua variabel $f(x, y)$ yang memiliki turunan ketiga yang kontinu dan $(a, b)$ merupakan titik kritis, dan

$\Delta=f_{x x}(a, b) f_{y y}(a, b)-\left[f_{x y}(a, b)\right]^{2}$ dinamakan diskriminan fungsi $\mathrm{f}$.

a. Jika $\Delta>0$, dan

- $f_{\mathrm{xx}}(\mathrm{a}, \mathrm{b})>0$, maka titik (a, b)merupakan titik minimum lokal

- $f_{\mathrm{xx}}(\mathrm{a}, \mathrm{b})<0$, maka titik $(\mathrm{a}, \mathrm{b})$ merupakan titik maksimum lokal

b. Jika $\Delta=0$, tes gagal sehingga diperlukan pengujian lebih lanjut, dan titik kritisnya disebut titik kritis trivial.

c. Jika $\Delta<0$, maka titik (a, b) merupakan titik pelana.

\subsubsection{Median Rank Regression Estimation (MRRE)}

Menurut Kumar et al. (2006)setelah membandingkan estimasi parameter untuk distribusi Weibull dengan Median Rank Regression Estimation (MRRE) dengan Maximum Likelihood Estimation (MLE) pada studi kasus kegagalan komponen dengan menggunakan ukuran sampel yang kecil $(<30)$ maka diperoleh kesimpulan bahwa MRRE cenderung memberikan estimasi yang lebih baik pada parameter bentuk, selain itu MRRE digunakan sebagai metode alternatif dalam mengestimasi parameter yang tidak dapat diselesaikan secara analitik. MRRE menggunakan penaksiran Bernard untuk mendapatkan peluang kumulatif kegagalan, persamaan tersebut adalah sebagai berikut, 


$$
\hat{F}\left(t_{i}\right)=\frac{i-0,3}{n+0,4}
$$

$i$ adalah peringkat terurut dari data dan $n$ adalah banyaknya data. Estimasi ini digunakan dalam menentukan model regresi, kemudian fungsi distribusi yang terbentuk akan digunakan untuk menurunkan hubungan linier antara transformasi estimasi fungsi distribusi dengan log waktu keandalannya hingga didapat nilai estimasi parameter.

\subsection{Estimasi Parameter}

Tabel 2. Perhitungan untuk Mengestimasi Parameter

\begin{tabular}{cccc}
\hline No & Distribusi & Parameter & Estimasi Parameter \\
\hline 1 & Normal & $\mu, \sigma$ & $\hat{\mu}=\frac{\sum_{i=1}^{n} t_{i}}{n}$ \\
& & & $\hat{\sigma}=\sqrt{\frac{\sum_{i=1}^{n}\left(t_{i}-\mu\right)^{2}}{n}}$ \\
& & & \\
& Gamma & $\alpha, \beta$ & $\hat{\alpha}=\frac{\bar{T}}{\hat{\beta}}$ \\
& & & $\hat{\beta}=\frac{1}{n} \sum_{i=1}^{n}\left(t_{i}-\bar{T}\right)^{2}$ \\
$\bar{T}$ \\
& Weibull & $\eta, \beta$ & $\hat{\eta}=\exp \left(-\frac{a}{\hat{\beta}}\right)$ \\
& & & $\hat{\beta}=\frac{n \sum_{i=1}^{n}\left(x_{i} y_{i}\right)-\sum_{i=1}^{n} x_{i} \sum_{i=1}^{n} y_{i}}{n \sum_{i=1}^{n} x_{i}{ }^{2}-\left(\sum_{i=1}^{n} x_{i}\right)^{2}}$ \\
\hline
\end{tabular}

\subsection{Uji Anderson-Darling}

Uji Anderson-Darling (AD) digunakan untuk menguji apakah data berasal dari populasi yang mengikuti distribusi khusus. Nilai-nilai kritis dalam uji KS tidak tergantung pada distribusi tertentu yang sedang diuji sedangkan uji Anderson-Darling memanfaatkan distribusi tertentu dalam menghitung nilai kritis. Ini memiliki keuntungan yang memungkinkan tes yang lebih sensitif namun kelemahannya adalah nilai-nilai kritis harus dihitung untuk setiap distribusi (Fallo, Setiawan, dan Susanto, 2013).

Langkah-langkah untuk uji Anderson-Darling adalah sebagai berikut (Astarini dan Haryono, 2015):

1. Menentukan hipotesis

$\mathrm{H}_{0}$ : Data mengikuti distribusi tertentu

$\mathrm{H}_{1}$ : Data tidak mengikuti distribusi tertentu

2. Menentukan taraf signifikansi

Pada penelitian ini digunakan interval kepercayaan $(1-\alpha) 100 \%$ dengan taraf signifikansi $\alpha=5 \%$

3. Statistik uji

$$
A=-n-\frac{1}{n} \sum_{i=1}^{n}(2 i-1)\left[\ln F\left(x_{i}\right)+\ln \left(1-F\left(x_{n+1-i}\right)\right)\right]
$$

Adjusted Anderson-Darling: 
Distribusi Normal

$$
: A^{*}=A\left(1+\frac{0,75}{n}+\frac{2,25}{n^{2}}\right)
$$

Distribusi Gamma $(\mathrm{k}>1)$

$$
: A^{*}=A+\frac{0,2+0,3 / k}{n}
$$

Distribusi Weibull

$$
: A^{*}=A\left(1+\frac{0,2}{\sqrt{n}}\right)
$$

dengan,

$F$ : Fungsi distribusi kumulatif

$x_{i}$ : Data pengamatan terurut

$n$ : Banyak data pengamatan

$k: 0,1, \ldots, n-1$

4. Kriteria penolakan

Jika $A^{*}>c_{\alpha}$ maka $\mathrm{H}_{0}$ ditolak yang artinya data tidak mengikuti distribusi yang diduga. Pada distribusi normal nilai kritis $c_{\alpha}$ perlu dilakukan perhitungan sebagai berikut,

$$
c_{\alpha}=a_{\alpha}\left(1+\frac{b_{0}}{n}+\frac{b_{1}}{n^{2}}\right)
$$

\subsection{Analisis Reliabilitas}

\subsubsection{Ketentuan Analisis Reliabilitas}

Terdapat 3 hal yang harus diperhatikan dalam menentukan waktu ketahanan hidup

(T) secara tepat menurut Collet (2004) dalam Pratiwi (2015), yaitu:

1. Waktu awal tidak ambigu yang berarti tidak ada dua pengertian atau lebih.

2. Definisi terjadinya kegagalan secara keseluruhan harus jelas.

3. Skala waktu sebagai satuan pengukuran harus jelas.

\subsubsection{Fungsi-Fungsi Pengukuran Reliabilitas}

Terdapat tiga fungsi untuk menganalisis ketahanan hidup padadata waktu kegagalan diantaranya:

1. Fungsi Kepadatan Peluang (Probability Density Function)

Fungsi ini dinotasikan dengan $f(t)$, dan didefinisikan sebagai probabilitas kegagalan suatu obyek pada suatu interval $(t, t+\Delta t)$ per satuan waktu. Fungsi densitas probabilitas dinyatakan dengan:

$$
f(t)=\lim _{\Delta t \rightarrow 0}\left[\frac{P(t<T<t+\Delta t)}{\Delta t}\right]
$$

2. Fungsi Ketahanan Hidup (Reliability Function)

Fungsi reliabilitas merupakan sebuah fungsi yang menggambarkan komponen berjalan dengan baik dalam suatu satuan waktu t.

$$
\begin{aligned}
& R(t)+F(t)=1 \\
& R(t)=1-F(t)
\end{aligned}
$$

3. Fungsi Kegagalan (Hazard Function)

Fungsi kegagalan dinotasikan dengan $\lambda(t)=h(t)$, dan didefinisikan sebagai probabilitas suatu obyek gagal di dalam interval waktu $(t, t+\Delta t)$ dengan diketahui bahwa obyek tersebut telah hidup selama waktu $t$. 


$$
\lambda(t)=h(t)=\lim _{\Delta t \rightarrow 0}\left[\frac{P(t<T<t+\Delta t \mid T>t)}{\Delta t}\right]=\frac{f(t)}{R(t)}
$$

\subsection{Sistem Komponen Seri-Paralel}

\subsubsection{Sistem dan Komponen}

Adapun contoh komponen yang disusun menjadi sebuah sistem seri-paralel adalah rangkaian filter kapasitor. Filter atau tapis pada power supply merupakan bagian yang difungsikan untuk meratakan atau membuang riak gelombang hasil proses penyearahan tegangan AC (alternating current) dari transformer oleh dioda penyearah. Rangkaian tersebut dapat disusun secara seri-paralel dengan menggunakan empat buah komponen yaitu dua dioda penyearah, kapasitor dan resistor beban.

\subsubsection{Fungsi Bentuk}

Menurut Sudarno (2004), untuk mengetahui suatu sistem berfungsi atau tidak, dapat dilihat dari fungsi bentuk. Untuk menunjukkan apakah komponen ke-j berfungsi atau tidak, didefinisikan variabel indikator $x$ dengan,

$$
x_{j}=\left\{\begin{array}{l}
1, \text { komponenke-jberfungsi } \\
0, \text { komponenke-jtidakberfungsi }
\end{array}\right.
$$

Vektor $\boldsymbol{x}=\left(x_{1}, \ldots, x_{n}\right)$ disebut vektor state, yang menunjukkan komponenkomponennya berfungsi atau tidak. Misal terdapat fungsi $\Phi(\boldsymbol{x})$ sedemikian hingga,

$$
\Phi(x)=\left\{\begin{array}{l}
1, \text { jikasistemberfungsi } \\
0, \text { jikasistemmati }
\end{array}\right.
$$

Fungsi $\Phi(\boldsymbol{x})$ disebut fungsi bentuk dari sistem tersebut. Fungsi bentuk memiliki nilai yang berbeda bergantung dengan konfigurasi rangkaian sistem yang digunakan. Untuksistem seri-paralel yang dirangkai dengan menggunakan $j$ komponen dalam subsistem $i$ maka dapat dinyatakan fungsi bentuknya dengan,

$$
\begin{aligned}
\Phi(\boldsymbol{x}) & =\max _{1}\left(x_{1}, x_{2}, \ldots, x_{m}\right) \ldots \max _{\mathrm{n}}\left(x_{1}, x_{2}, \ldots, x_{m}\right) \\
& =\left(1-\left(1-x_{1}\right)\left(1-x_{2}\right) \ldots\left(1-x_{m}\right)\right) \ldots\left(1-\left(1-x_{1}\right)\left(1-x_{2}\right) \ldots\left(1-x_{m}\right)\right)
\end{aligned}
$$

\subsubsection{Reliabilitas Sistem Komponen Seri-Paralel}

Pada umumnya sistem seri-paralel terdiri dari $n$ subsistem yang disusun secara seri dan pada setiap subsistem disusun sejumlah $m$ unit secara paralel, berdasarkan hal tersebut maka diperoleh perhitungan sistemreliabilitas seri-paralel sebagai berikut,

$$
R_{\text {sistemsp }}=\prod_{i=1}^{n}\left[1-\prod_{j=1}^{m}\left(1-P\left(x_{i j}\right)\right)\right]
$$

\section{METODE PENELITIAN}

\subsection{Sumber Data dan Variabel Penelitian}

Data penelitian yang digunakan dalam studi literature pada tugas akhir ini merupakan data simulasi. Penggunaan data simulasi disebabkan oleh terbatasnya kemampuan peneliti untuk mendapatkan data primer dan sekunder sesuai dengan contoh studi kasus penelitian.

\subsection{Variabel Penelitian}

1. Waktu Kegagalan Dioda Penyearah ${ }_{1}\left(T_{D 1}\right)$ 
2. Waktu Kegagalan Dioda Penyearah ${ }_{2}\left(T_{D 2}\right)$

3. Waktu Kegagalan Kapasitor $\left(T_{K}\right)$

4. Waktu Kegagalan Resistor Beban $\left(T_{R}\right)$

\subsection{Metode Penelitian}

Metode penelitian yang digunakan dalam penulisan tugas akhir ini adalah metode kepustakaan dan contoh kasus.

\subsection{Teknik Pengolahan Data}

Jenis data penelitian yang digunakan adalah rasio yang diperoleh dari membangkitkan data, kemudian dilakukan olah data pula dengan menggunakan software $\mathrm{R}$ i386 3.2.3.

\subsection{Tahapan Analisis Data}

1. Membangkitkan data variabel.

2. Melakukan pendugaan nilai parameter dengan MRRE dan MLE.

3. Pengujian kecocokan distribusi secara manual menggunakan metode AD.

4. Bila setelah uji AD disimpulkan data tidak signifikan mengikuti distribusi tertentu, maka proses diselesaikan tanpa menghitung fungsi pengukuran reliabilitas.

5. Menghitung secara manual nilai fungsi kepadatan peluang, nilai fungsi distribusi kumulatif, nilai fungsi reliabilitas, dan nilai fungsi kegagalan pada tiap variabel.

6. Menggambarkan plot.

7. Menghitung secara manual reliabilitas sistem seri-paralel.

\section{HASIL DAN PEMBAHASAN}

\subsection{Susunan Sistem Komponen Seri-Paralel}

Studi kasus yang digunakan dalam penelitian adalah suatu sistem filter kapasitor pada power supply. Rangkaian sistem seri-paralel yang terbentuk diberikan pada gambar berikut.

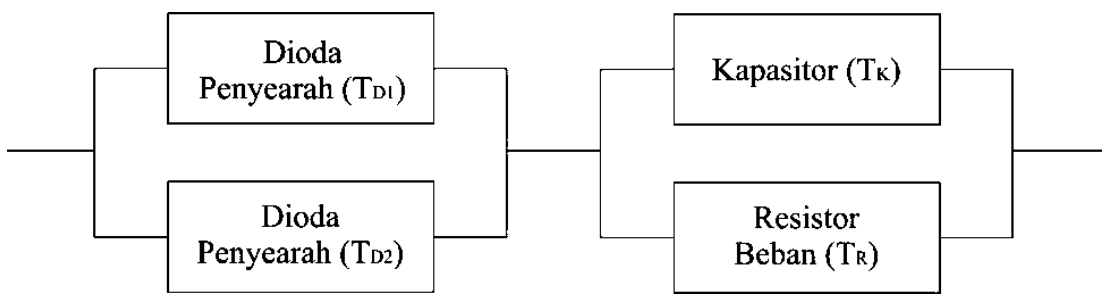

Gambar 1. Sistem Seri-Paralel pada Filter Kapasitor

\subsection{Fungsi Bentuk}

Fungsi $\Phi(\mathrm{x})$ merupakan fungsi bentuk yang terbentuk dari sistem.

$$
\Phi(x)=\left\{\begin{array}{l}
1, \text { jika sistemberfungsi } \\
0, \text { jikasistemmati }
\end{array}\right.
$$

Untuksistem seri-paralel yang dirangkai dengan menggunakan 4 komponen dalam 2 subsistem maka dapat dinyatakan fungsi bentuknya dengan,

$$
\begin{aligned}
\Phi(\boldsymbol{x}) & =\max \left(x_{1}, x_{2}\right) \cdot \max \left(x_{3}, x_{4}\right) \\
& =x_{1} x_{3}+x_{1} x_{4}+x_{2} x_{3}+x_{2} x_{4}-x_{1} x_{3} x_{4}-x_{2} x_{3} x_{4}-x_{1} x_{2} x_{3}-x_{1} x_{2} x_{4}+x_{1} x_{2} x_{3} x_{4}
\end{aligned}
$$




\subsection{Estimasi Parameter}

Tabel 3. Nilai Estimasi Parameter untuk Masing-Masing Komponen

\begin{tabular}{|c|c|c|c|c|}
\hline No & Komponen & $\begin{array}{c}\text { Metode } \\
\text { Estimasi }\end{array}$ & Parameter & $\begin{array}{c}\text { Estimasi } \\
\text { Parameter }\end{array}$ \\
\hline 1 & Dioda Penyearah $1\left(\mathrm{~T}_{\mathrm{D} 1}\right)$ & MRRE & $\eta, \beta$ & $\begin{array}{l}\hat{\eta}=42119,960 \\
\hat{\beta}=13,313\end{array}$ \\
\hline 2 & Dioda Penyearah $2\left(\mathrm{~T}_{\mathrm{D} 1}\right)$ & MRRE & $\eta, \beta$ & $\begin{array}{l}\hat{\eta}=42776,606 \\
\hat{\beta}=20,831\end{array}$ \\
\hline 3 & Kapasitor $\left(\mathrm{T}_{\mathrm{K}}\right)$ & MLE & $\mu, \sigma$ & $\begin{array}{l}\hat{\mu}=42966,192 \\
\hat{\sigma}=384,3371\end{array}$ \\
\hline 4 & Resistor Beban $\left(T_{R}\right)$ & MLE & $\alpha, \beta$ & $\begin{array}{l}\hat{\alpha}=371,997 \\
\hat{\beta}=115,910\end{array}$ \\
\hline
\end{tabular}

\section{○ Uji Kecocokan Distribusi}

Berikut merupakan uji kecocokan distribusi terhadap data waktu kegagalan komponen dengan menggunakan perhitungan Anderson-Darling.

Langkah-langkah dalam analisis yang perlu dilakukan diantaranya:

- Hipotesis

$\mathrm{H}_{0}$ : Data mengikuti distribusi yang diduga

$\mathrm{H}_{1}$ : Data tidak mengikuti distribusi yang diduga

- Taraf signifikansi

$\alpha=5 \%$

- Kriteria Penolakan

$\mathrm{H}_{0}$ ditolak apabila $\mathrm{A}^{*}>\mathrm{c}_{\alpha}$

Tabel 4. Hasil Uji Kecocokan Distribusi secara Perhitungan Manual

\begin{tabular}{clcccc}
\hline No & \multicolumn{1}{c}{ Komponen } & Nilai A & Nilai A* & $\begin{array}{c}\text { Nilai } \\
\text { Kritis c }\end{array}$ & \multicolumn{1}{c}{ Kesimpulan } \\
\hline 1 & Dioda Penyearah 1 $\left(\mathrm{T}_{\mathrm{D} 1}\right)$ & 0,448 & 0,461 & 0,757 & $\begin{array}{c}\text { Variabel mengikuti } \\
\text { distribusi Weibull }\end{array}$ \\
2 & Dioda Penyearah 2 $\left(\mathrm{T}_{\mathrm{D} 1}\right)$ & 0,591 & 0,607 & 0,757 & $\begin{array}{c}\text { Variabel mengikuti } \\
\text { distribusi Weibull }\end{array}$ \\
3 & Kapasitor ( $\left.\mathrm{T}_{\mathrm{K}}\right)$ & 0,273 & 0,277 & 0,739 & $\begin{array}{c}\text { Variabel mengikuti } \\
\text { distribusi normal }\end{array}$ \\
4 & Resistor Beban $\left(\mathrm{T}_{\mathrm{R}}\right)$ & 0,314 & 0,318 & 0,752 & $\begin{array}{c}\text { Variabel mengikuti } \\
\text { distribusi gamma }\end{array}$ \\
\hline
\end{tabular}

○ Fungsi Pengukuran Reliabilitas

Fungsi pengukuran reliabilitas terdiri atas tiga fungsi; fungsi kepadatan peluang $f(t)$, fungsi reliabilitas $R(t)$, serta fungsi kegagalan $h(t)$.

Berdasarkan uji distribusi yang telah dilakukan, variabel $\mathrm{T}_{\mathrm{D} 1}$ terbukti mengikuti distribusi Weibull dengan nilai parameter $\hat{\beta}=13,313$ dan $\hat{\eta}=42119,960$ sehingga bila nilai fungsi kepadatan peluang, fungsi reliabilitas dan fungsi kegagalan dibentuk kedalam plot fungsi akan nampak penyebaran nilai fungsi pengukuran reliabilitas sebagai berikut: 


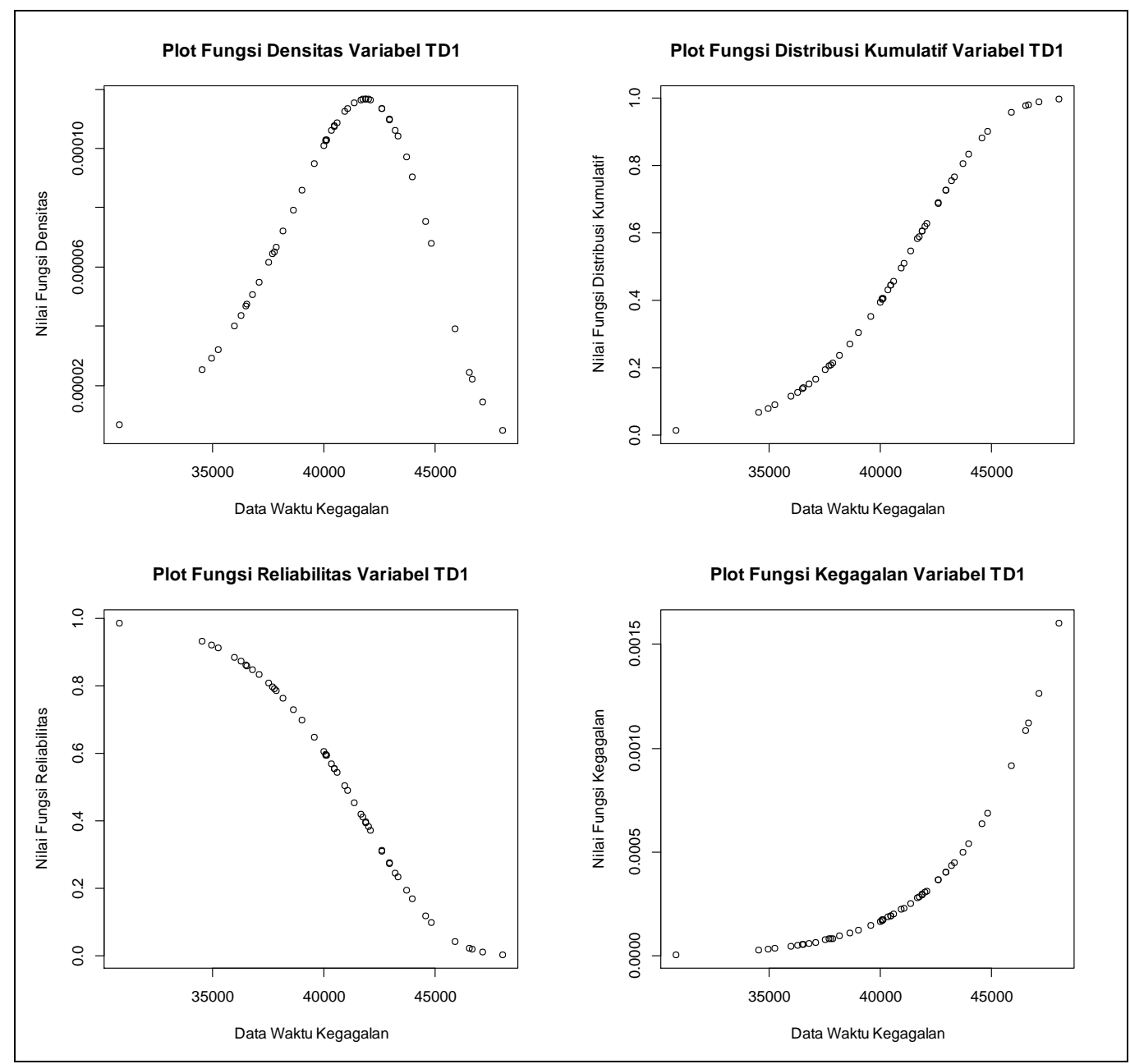

Gambar 3. Plot Fungsi Reliabilitas dan Kegagalan Variabel $T_{D 1}$

Dilakukan analisis perhitungan dan pembuatan plot fungsi yang serupa untuk ketiga variabel lainnya pula.

\section{- Fungsi Reliabilitas}

Berdasarkan hasil perhitungan reliabilitas sistem maka diketahui bahwa peluang sistem mampu bertahan pada waktu kegagalan pertama kali dari tiap komponen yaitu, pada waktu 30817,86 jam untuk komponen dioda penyearah 1; 36405,25 jam untuk komponen dioda penyearah 2; 42016,40 jam untuk komponen kapasitor; serta 38439,34 untuk komponen resistor beban adalah 0,999366 atau jika dirubah dalam satuan jam menjadi 42972,738. Peluang sistem mampu bertahan hidup pada waktu kegagalan komponen ke-2 adalah 0,994551 dan begitu seterusnyahingga waktu kegagalan komponen ke-50.

\section{KESIMPULAN}

Berdasarkan pada bab hasil dan pembahasan maka dapat ditarik kesimpulan sebagai berikut: 
1. Fungsi bentuk dari sistem seri-paralel yang dirangkai dengan menggunakan empat komponen dalam dua subsistem adalah $\Phi(x)=x_{1} x_{3}+x_{1} x_{4}+x_{2} x_{3}+x_{2} x_{4}-x_{1} x_{3} x_{4}-x_{2} x_{3} x_{4}-$ $x_{1} x_{2} x_{3}-x_{1} x_{2} x_{4}+x_{1} x_{2} x_{3} x_{4}$.

2. Dari estimasi parameter dengan menggunakan metode MRRE untuk data berdistribusi Weibull pada variabel $\mathrm{T}_{\mathrm{D} 1}$ diperoleh nilai $\hat{\beta}=13,313$ dan $\hat{\eta}=42119,960$, pada variabel $\mathrm{T}_{\mathrm{D} 2}$ diperoleh nilai $\hat{\beta}=20,831$ dan $\hat{\eta}=42776,606$. Dari estimasi parameter dengan menggunakan metodeMLE untuk data berdistribusi normal pada variabel $\mathrm{T}_{\mathrm{K}}$ diperoleh nilai $\hat{\mu}=42966,192$ dan $\hat{\sigma}=384,337$, sedangkan pada variabel $\mathrm{T}_{\mathrm{R}}$ diperoleh nilai $\hat{\alpha}=371,997$ dan $\hat{\beta}=115,910$.

3. Pada uji kecocokan distribusi dengan menggunakan Anderson-Darling untuk $\alpha=5 \%$ diketahui bahwa data pada variabel $\mathrm{T}_{\mathrm{D} 1}$ dan $\mathrm{T}_{\mathrm{D} 2}$ mengikuti distribusi Weibull, data pada variabel $T_{K}$ mengikuti distribusi normal, serta data pada variabel $T_{R}$ mengikuti distribusi gamma.

4. Berdasarkan fungsi pengukuran reliabilitas yang telah dilakukan pada masing-masing variabel maka dapat dilihat bahwa plot nilai fungsi kepadatan peluang data waktu kegagalan komponen mengikuti kurva fungsi densitas tiap distribusinya; untuk plot nilai fungsi reliabilitas jika data waktu kegagalan komponen $t_{i}$ semakin besar maka nilai reliabilitas akan semakin kecil sehingga bila telah mencapai waktu maksimal penggunaan, reliabilitas komponen akan bernilai nol; namun terjadi hal sebaliknya untuk plot nilai fungsi kegagalan yang jika data waktu kegagalan komponen $t_{i}$ semakin besar maka nilai kegagalan akan semakin besar pula.

5. Dari perhitungan reliabilitas sistem, menunjukkan bahwa semakin tinggi intensitas sistem mengalami kegagalan akan mempengaruhi nilai reliabilitas menjadi semakin rendah.

\section{DAFTAR PUSTAKA}

Anugraheni, A. 2013. Kajian Availabilitas pada Sistem Komponen Seri.Jurnal Gaussian. Vol. 2, No. 3, Halaman 187-196.

Astarini, L.A.A.D. dan Haryono. 2015. Analisis Reliabilitas dan Availabilitas pada Mesin Produksi dengan Sistem Seri Menggunakan Pendekatan Analisis Markov di PT."X". Jurnal Sains dan Seni ITS. Vol. 4, No.1, Halaman D7-D12.

Bain, L.J. and Engelhardt, M. 1992. Introduction to Probability and Mathematical Statistics, Second Edition. California: Duxbury Press.

Budhi, W.S. 2001. Kalkulus Peubah Banyak dan Penggunaannya. Bandung: Penerbit ITB.

Elsayed, A.E. 1996. Reliability Engineering. Massachusets: Addison Wesley Longman, Inc.

Fallo, J.O., Setiawan, A., dan Susanto, B. 2013. Uji Normalitas Berdasarkan Metode Anderson-Darling, Cramer-Von Mises dan Lilliefors menggunakan Metode Bootstrap. Prosiding Seminar Nasional Matematika dan Pendidikan Matematika. ISBN: 978-979-16353-9-4.

Kumar, U.D., John Crocker, T. Chitra, and Haritha Saranga. 2006. Reliability and Six Sigma. New York: Springer.

Nuroqi, F.S. 2017. Kajian Reliabilitas pada Sistem Komponen Paralel-Seri.Jurnal Gaussian. Vol. 4, No. 3, Halaman 687-696.

Pratiwi, D.I. 2015. Penggunaan Analisis Ketahanan Hidup untuk Penentuan Periode Garansi dan Harga Produk pada Data Waktu Hidup Lampu Neon.Jurnal Gaussian. Vol. 4, No. 3, Halaman 463-476. 
Pradewi, R.A.A. 2014. Kajian Reliabilitas dan Availabilitas pada Sistem Komponen Paralel. Jurnal Gaussian. Vol. 3, No. 2, Halaman 243-252.

Sudarno. 2004. Taksiran Umur Sistem dengan Umur Komponen Berdistribusi Seragam.Jurnal Matematika dan Komputer. Vol. 7, No. 1, Halaman 11-19.

Spiegel, M.R. 1988. Seri Buku Schaum Teori dan Soal-Soal Statistika, Edisi Kedua. Terjemahan oleh Drs. I Nyoman Susila, M.Sc, Dra. Ellen Gunawan, M.A. Jakarta: Erlangga. 